\title{
Role of Acinetobacter sp. CS9 in Improving Growth and Phytoremediation Potential of Catharanthus longifolius under Cadmium Stress
}

\author{
Nasim Ahmad Yasin ${ }^{1}$, Waheed Ullah Khan', Sajid Rashid Ahmad ${ }^{2}$, Aqeel Ahmad ${ }^{1}$, \\ Waheed Akram', Madiha Ijaz ${ }^{2}$ \\ ${ }^{1}$ University of the Punjab, Lahore, Pakistan \\ ${ }^{2}$ College of Earth and Environmental Sciences, University of the Punjab, Lahore, Pakistan
}

Received: 29 August 2017

Accepted: 25 November 2017

\begin{abstract}
Some rhizobacteria are capable of improving metal tolerance and growth of plants under heavy metal stress. The objective of the current study was isolation and subsequent application of cadmium-resistant rhizobacteria in phytoremediation by Catharanthus longifolius. The screened bacterial isolate exhibited growth-promoting attributes, including phosphate solubilization, ACCD activity, auxin, and siderophores production. The inoculation of Acinetobacter sp. CS9 under greenhouse trial improved growth and phytoextraction capability of $C$. longifolius plants in soils contaminated with different concentrations $\left(0,100\right.$, and $\left.200 \mathrm{mg} \mathrm{kg}^{-1}\right)$ of $\mathrm{Cd}$. The plants exhibited reduced quantity of total soluble protein, soluble sugars, and chlorophyll contents under Cd stress. On the other hand, improved chlorophyll, soluble protein, and sugar contents were observed in Acinetobacter sp. CS9-treated plants. The inoculated plants exhibited improved activity of antioxidant enzymes (SOD and CAT) and reduced malondialdehyde levels. Moreover, higher Cd uptake and translocation ratio was observed in Acinetobacter sp. CS9-inoculated plants as compared to un-inoculated ones. The current study showed that Acinetobacter sp. CS9 reduced Cd-induced oxidative stress and improved the phytoremediation capability of $C$. longifolius.
\end{abstract}

Keywords: Acinetobacter sp., cadmium, Catharanthus longifolius, phytoremediation, stress

\section{Introduction}

The agricultural lands of Pakistan adjacent to industrial areas are severely contaminated with heavy metals, including $\mathrm{Cd}, \mathrm{Cu}, \mathrm{Zn}$, and $\mathrm{Ni}$ [1]. Crop productivity is

*e-mail: waheedenviro@gmail.com reduced on polluted soils and the presence of these heavy metals in the food chain has caused a number of health issue in humans and animals [2]. Cadmium is one of the injurious heavy metals that may be extremely phytotoxic to some plant species even at very low concentrations [3]. The improper disposal of effluents released during the process of smelting and electroplating in conjunction with burning of urban waste cause Cd contamination [4]. The metal-polluted area may be reclaimed by growing 
hyper-accumulator plants [5]. This process for metals removal, called phytoremediation, is an economically feasible and environmentally safe technique [6]. Our previous research has shown that Catharanthus species may be used for the phytoextration of copper and lead [7]. Some other researchers have also demonstrated the potential of these species for phytoremediation of $\mathrm{Pb}$-, $\mathrm{Cr}-$, and Ni-contaminated soils [8-10], which is why C. longifolius - a cosmopolitan ornamental plant belonging to Catharanthus genus - was evaluated for its potential regarding phytoremediation of Cd-contaminated soil.

The lipid peroxidation caused by increased production of reactive oxygen species (ROS) enhances the membrane permeability in plants under Cd stress [11]. The superoxide dismutase (SOD) helps plants overcome this oxidative stress by dismutation of $\mathrm{O}_{2}^{-}$to $\mathrm{O}_{2}$ and $\mathrm{H}_{2} \mathrm{O}_{2}$ [12]. Similarly, peroxidase (POD), ascorbate peroxidase (APX), and catalase (CAT) detoxify $\mathrm{H}_{2} \mathrm{O}_{2}$ [13]. Moreover, the formation of phytochelatins and metal complex help in detoxifying or distributing injurious metals to specific parts of the plants [14]. However, most of the hyper-accumulator plants recognized hitherto exhibit poor growth, biomass production, and phytoremediation potential in soils polluted by higher concentrations of heavy metal [15].

The rhizospheric microbes associated with plant roots may manipulate plant growth and uptake of heavy metals in an environmentally safe manner [16]. These microorganisms are capable of enhancing the mobility and subsequent bioavailability of heavy metals [17]. Certain rhizobacteria that have the ability to produce siderophore and plant hormones improve uptake and translocation of metalloids in assisted plants [18]. The rhizobacteria having growth promoting attributes such as synthesis of phytohormones, nitrogen fixation, solubilization of phosphate, and other nutrients may improve plant growth. These soil-inhabitant bacteria are termed plant growth-promoting rhizobacteria (PGPR). These PGPR assist inoculated plants in alleviating heavy metal stress [19-20]. Consequently, the intentions of current research were: (1) screening and identifying Cd-resistant rhizobacteria, (2) assessing growthpromoting attributes of screened bacterium, and (3) evaluating the $\mathrm{Cd}$ phytoextraction and stress-alleviating capability of inoculated and un-inoculated C. longifolius plants.

\section{Material and Methods}

\section{Procuring Rhizobacteria}

For the isolation of Cd-resistant rhizobacteria, $10 \mathrm{~g}$ composite rhizospheric soil obtained from healthy C. longifolius plants growing in soil polluted by heavy metal-contaminated industrial effluents was mixed thoroughly in $90 \mathrm{ml}$ distilled sterilized water [21]. From soil sample $10^{-6}$ serial dilution was spread plated on $\mathrm{LB}$ media supplemented with $\mathrm{CdCl}_{2}\left(200 \mathrm{mg} \mathrm{l}^{-1} \mathrm{Cd}\right)$ and incubated for 3 days at $28^{\circ} \mathrm{C}$. The rhizobacteria with distinguished bacterial colony was cultured on Cd-contaminated media according to the spread plate technique [22].

\section{Analyzing Minimum Inhibitory Concentration (MIC)}

The obtained bacterial isolates were cultured on different concentrations of Cd-contaminated LB media at $28^{\circ} \mathrm{C}$ for $72 \mathrm{~h}$ to assess MIC value according to the European food safety authority (EFSA) in Parma, Italy (2012) [23].

\section{Identifying Screened Rhizobacteria}

From the isolated Cd-resistant rhizobacteria, the uppermost Cd-resistant CS9 (250 $\mathrm{mg} \mathrm{l}^{-1} \mathrm{Cd}$; MIC) was identified by observing morphological and biochemical tests [24]. The bacterial identification was further confirmed by $16 \mathrm{~s}$ rRNA gene analysis. The genomic DNA of bacterial isolate was extracted with the help of a QIAGEN genomic DNA isolation kit following the manufacturer's guidelines. The universal primers $27 \mathrm{~F}$ (5'-AGA GTT TGA TCC TGG CTC AG-3') and 1492R (5'- GGT TAC CTT GTT ACG ACT T-3') were employed for the amplification of 16S rRNA gene followed by performing PCR in the thermocycler. After amplifying 16S rRNA, products were purified using a PCR purification kit. The big dye terminator cycle sequencing kit was used to sequence the product. The sequence obtained for Acinetobacter sp. CS9 was matched with an existing sequence in the database Gene Bank by means of NCBI BLAST and submitted to the Gene Bank. The screened rhizobacteria was also deposited in the Bacterial Conservatory, Institute of Agricultural Sciences, University of the Punjab Lahore Pakistan under accession number 686.

\section{Quantifying Water-Extractable Cadmium from Soil}

For determining water-extractable $\mathrm{Cd}, 4 \mathrm{~g}$ of inoculated and un-inoculated soil sample was mixed in $40 \mathrm{ml}$ water and placed in a shaker at $25^{\circ} \mathrm{C}$. After $48 \mathrm{~h}$, soil suspension was centrifuged and filtered supernatant was used for assessing Cd [25].

\section{Growth-Promoting Attributes of Acinetobactor sp. CS9}

We observed the indole acetic acid (IAA) production capability of screened bacterial isolate. For this purpose, the $50 \mu \mathrm{l}$ of bacterial cells suspended in saline solution $(0.9 \%)$ were inoculated in an agar plate placed in shade for $72 \mathrm{~h}$ at $28^{\circ} \mathrm{C}$. Then Salkowsky reagent $(200 \mu \mathrm{l})$ was also applied over bacterial cells. The formation of pink colour after $0.5 \mathrm{~h}$ was an indication of auxin-producing 
capability [26]. The screened bacterial isolate was inoculated in plates containing Pikovskyaya's medium containing $6 \mathrm{gl}^{-1} \mathrm{NaCl}$ supplemented with insoluble tricalcium to determine phosphate solubilization capability. The inoculated plates were placed at $38^{\circ} \mathrm{C}$ for $72 \mathrm{~h}$. The formation of clear halo in plates represented positive testing for phosphate solubilization [27].

The screened bacterial isolate was inoculated on chrome azurol S agar plates placed at $28^{\circ} \mathrm{C}$ for $72 \mathrm{~h}$. The formation of an orange halo surrounding the bacterial colony was regarded as a positive test for siderophore production capability [28]. The 1-aminocyclopropane1-carboxylate (ACC) deaminase (ACCD) activity was analyzed accordingly [29].

\section{Preparing the Bacterial Inoculum}

The rhizobacteria was cultured on LB broth placed on a rotary shaker $(120 \mathrm{rpm})$ at $28^{\circ} \mathrm{C}$. After $24 \mathrm{~h}$, the bacterial culture was centrifuged at $6,000 \times g$ for $5 \mathrm{~min}$. The concentration of bacterial cells was adjusted $\left(10^{8} \mathrm{CFU} \mathrm{ml}^{-1}\right)$ in sodium chloride solution $(0.8 \%)$ by taking absorbance at $610 \mathrm{~nm}$.

\section{Greenhouse Experiment}

The composite soil sample was air-dried and passed through a 6-mm plastic sieve. The physicochemical characteristics of loamy soil obtained from the Conventional and Non-Conventional Agricultural Farm at the University of the Punjab exhibited: $\mathrm{P} \quad 0.81 \mathrm{~g} \mathrm{~kg}^{-1}, \mathrm{~K} 2.95 \mathrm{~g} \mathrm{~kg}^{-1}, \mathrm{~N} 81.3 \mathrm{mg} \mathrm{kg}{ }^{-1}$, Cd $0.49 \mathrm{mg} \mathrm{kg}^{-1}$, Ni $0.96 \mathrm{mg} \mathrm{kg}^{-1}$, Zn $60.11 \mathrm{~g} \mathrm{~kg}^{-1}$, and OM $4.03 \mathrm{~g} \mathrm{~kg}^{-1}$, with $7.3 \mathrm{pH}$. All the living organisms from soil were killed by sterilizing at $121^{\circ} \mathrm{C}$ for $35 \mathrm{~min}$ [30]. While using $\mathrm{CdCl}_{2}$, this soil was contaminated with 0,100 , and $200 \mathrm{mg} \mathrm{Cd} \mathrm{kg}^{-1}$ soil. The contaminated soil was subjected to equilibrium with distilled sterilized water saturating for 30 days in a greenhouse at $25 \pm 3^{\circ} \mathrm{C}$. The soil samples $(2 \mathrm{~kg})$ were filled in the allotted plastic pots $\left(50 \mathrm{~cm}^{3}\right)$ devoid of bottom holes. The seeds of $C$. longifolius were soaked in Acinetobacter sp. CS9 inoculum for $30 \mathrm{~min}$. The distilled water was used for seed-soaking in case of non-inoculated treatments. The treated seeds were sown equidistantly in allotted pots $(5$ seed pot $^{-1}$ ). Each treatment had 3 replicates (three pots) and all pots were placed under greenhouse conditions at $25 \pm 3^{\circ} \mathrm{C}$ for 60 days and irrigated with equal amounts of distilled water every $2^{\text {nd }}$ day.

\section{Analyzing Lipid Peroxidation}

Lipid peroxidation was estimated by quantifying malondialdehyde (MDA) produced by the thiobarbituric acid reaction [31]. For this purpose, a fresh plant sample was mixed with ice-cold extraction buffer $(0.7 \%$ of $\mathrm{NaH}_{2} \mathrm{PO}_{4} .2 \mathrm{H}_{2} \mathrm{O}$ and $1.6 \% \mathrm{Na}_{2} \mathrm{HPO}_{4} .12 \mathrm{H}_{2} \mathrm{O}$ ) using a mortar and pestle. The homogenate was centrifuged at $14,000 \times \mathrm{g}$ for $0.5 \mathrm{~h}$. The one $\mathrm{ml}$ resulting supernatant was homogenized with $4 \mathrm{ml}$ of $0.5 \%(\mathrm{w} / \mathrm{v})$ thiobarbituric acid solution supplemented with $20 \%$ (w/v) thiobarbituric acid. This solution was placed at $95^{\circ} \mathrm{C}$ for $0.5 \mathrm{~h}$ and cooled immediately. The colorimetric value of the solution was observed at $532 \mathrm{~nm}$, while correction for non-specific absorbance was accomplished by deducting the absorbance value obtained at $600 \mathrm{~nm}$. The amount of MDA was evaluated from its molar extinction coefficient $\left(155 \mathrm{mM}^{-1} \mathrm{~cm}^{-1}\right)$.

\section{Assessing Enzymatic Activity}

The frozen fresh plant samples were ground with the help of an ice-cold mortar and pestle. For evaluating SOD activity, a ground plant sample was homogenized with $3 \mathrm{~mL}$ of $100 \mathrm{mM}$ K-phosphate extraction buffer (pH 7.8), EDTA (0.1 mM), 2-mercaptoethanol (14 mM), and Triton X-100 $(0.1 \% \mathrm{v} / \mathrm{v})$. Whereas for evaluation of CAT and APX activity, the ground plant sample was homogenized with $50 \mathrm{mM}$ K-phosphate extraction buffer (pH 7.0), EDTA (2 mM), ascorbate $(20 \mathrm{mM})$, and Triton $\mathrm{X}-100(0.1 \% \mathrm{v} / \mathrm{v})$. The homogenates were centrifuged at $15000 \times \mathrm{g}$ at $4^{\circ} \mathrm{C}$ for $15 \mathrm{~min}$ and supernatant were used for determining total soluble protein [32] and subsequent enzyme activity.

For evaluating SOD cativity, the absorbance of reaction mixture having $50 \mathrm{mM} \mathrm{K}$ phosphate buffer $(\mathrm{pH} 7.8)$ EDTA $(0.1 \mathrm{mM})$, methionine $(13 \mathrm{mM})$, nitrobluetetrazolium $(75 \mu \mathrm{M})$, riboflavin $(2 \mu \mathrm{M})$, and enzyme extract $(100 \mu \mathrm{l})$ was observed at $560 \mathrm{~nm}$ [33]. For assessing CAT activity, enzyme extract $(20 \mu \mathrm{l})$ was homogenated with reaction mixture $(3 \mathrm{~mL})$ having $100 \mathrm{mM}$ phosphate extraction buffer ( $\mathrm{pH} 7.0)$, EDTA $(0.1 \mathrm{mM})$, and $\mathrm{H}_{2} \mathrm{O}_{2}(0.1 \%)$. The reduced quantity of $\mathrm{H}_{2} \mathrm{O}_{2}$ in homogenate was estimated at $240 \mathrm{~nm}$ and calculated with the help of extinction coefficient [34]. For determining POD activity, enzyme extract $(0.1 \mathrm{ml})$ was homogenized with $20 \mathrm{mMl}^{-1}$ guaiacol $(50 \mu \mathrm{l})$ and $10 \mathrm{mMl}^{-1}$ phosphate buffer $(2.8 \mathrm{ml}$ at $\mathrm{pH} 7.0)$. The reaction mixture contained $40 \mathrm{mMl}^{-1} \mathrm{H}_{2} \mathrm{O}_{2}(50 \mu \mathrm{l})$. The oxidation of guaiacol to tetraguaiacol was observed at $470 \mathrm{~nm}$ for $1 \mathrm{~min}$ [35].

\section{Determining Soluble Sugar Contents}

For analysis of soluble sugars, the fine powder of plant samples $(100 \mathrm{mg})$ was thoroughly mixed with $80 \%$ (v/v) ethanol. The spectrophotometric value of this solution was observed after $72 \mathrm{~h}$ at $585 \mathrm{~nm}$ and compared with the standard curve of glucose [36].

\section{Determining Chlorophyll Content}

The chlorophyll contents from fresh leaves were analyzed by taking SPAD value with the help of a chlorophyll meter. 
Determining Plant Growth, Bioconcentration, and Translocation Factors

After 60 days, the treated C. longifolius plants were uprooted carefully, washed with tap water, and air-dried at room temperature. The number of leaves, root length, shoot lengths, and their respective fresh weight were measured. The dry weight of leaves, roots, and shoots were also measured by drying these samples in an oven at $120^{\circ} \mathrm{C}$ for $12 \mathrm{~h}$. The oven-dried leaves, root, and shoot samples were finely ground and the fine powders of these samples were digested with nitric acid-perchloric acid $(4: 1, \mathrm{v} / \mathrm{v})$ solution. The quantity of $\mathrm{Cd}$ present in plant tissues was analyzed using flame atomic absorption spectrophotometry. The bioconcentration factor (BCF) and translocation factor (TF) for $\mathrm{Cd}$ were measured from the following formulas:

$$
\begin{gathered}
\mathrm{BCF}=\frac{\mathrm{Cd} \text { contents in shoot }}{\mathrm{Cd} \text { contents in soil }} \\
\mathrm{TF}=\frac{\mathrm{Cd} \text { contents in shoot }}{\mathrm{Cd} \text { contents in root }}
\end{gathered}
$$

\section{Statistical Analysis}

The research trials were conducted using completely randomized design. There were three replicates for each treatment. The data were subjected to analysis of variance and tested at $P \leq 0 \cdot 05$ significance level using DSAASTAT software. Significance differences were estimated by Duncan's test.

\section{Results and Discussion}

\section{Cd-tolerance, Bacterial Identification, and Analysis of Growth-Promoting Characteristics}

The bacterial isolate that showed maximum MIC value for $\mathrm{Cd}\left(250 \mathrm{mg} \mathrm{l}^{-1}\right)$ was screened for downstream experimentation. This rod-shaped bacterium showed pale circular colony on petri plates. This rhizobacterium exhibited positive results for catalase, citrate, and arginine hydrolysis tests. It showed negative results for oxidase, motility, urease, nitrate reduction, hemolysis, gelatin hydrolysios, and Gram tests. According to Bergey's Manual, the screened bacterium was identified as Acinetobactor sp. This identification was confirmed by molecular identification. The isolate was assigned accession number Acinetobactor sp. CS9: KY026606 from NCBI. The similarity index analysis of said bacterium with already existing bacteria demonstrated that it had $98.56 \%, 96.53 \%, 95.87 \%$, and $91.30 \%$ alignment similarity with Acinetobacter sp. strain SZ051, Acinetobacter sp. strain Y15, Acinetobacter sp. strain 5L4, and Acinetobacter sp. AG-LSL1, respectively.
On the basis of minimum inhibitory concentration, bacterium was found resistant up to $250 \mathrm{mg} \mathrm{l}^{-1} \mathrm{Cd}$. Results showed that Acinetobacter sp. CS9 exhibited positive results for auxin and siderophores production. The strain also demonstrated phosphate solubilization and ACCD activity. According to our information, this is the first time that a native Acinetobacter sp. has exhibited plant growth-promoting attributes and $\mathrm{Cd}$ resistance.

\section{Effect of Acinetobactor sp. CS9 on Growth of $C$. longifolius Plants}

During our current study, reduced growth in terms of root length, shoot length, number of leaves, root, shoot, and leaves dry biomass was observed in C. longifolius plants cultivated in Cd-contaminated soils as compared to those growing in non-contaminated soils. However, Acinetobactor sp. CS9 inoculation improved the growth of $C$. longifolius plants grown either in the absence or presence of $\mathrm{Cd}$ stress (Fig. 1). Our results revealed that the shoot length, root length, number of leaves, and root, shoot, and leaves dry biomass declined up to $13 \%, 22 \%, 24 \%, 19 \%, 21 \%$, and $11 \%$, respectively, under the influence of $100 \mathrm{mg} \mathrm{kg}^{-1} \mathrm{Cd}$ as compared to non-contaminated control, whereas Acinetobactor sp. CS9 inoculation improved shoot length, root length, number of leaves and roots, and leaves as well as shoot dry weight up to $11 \%, 13 \%, 14,20 \%, 33 \%$, and $15 \%$
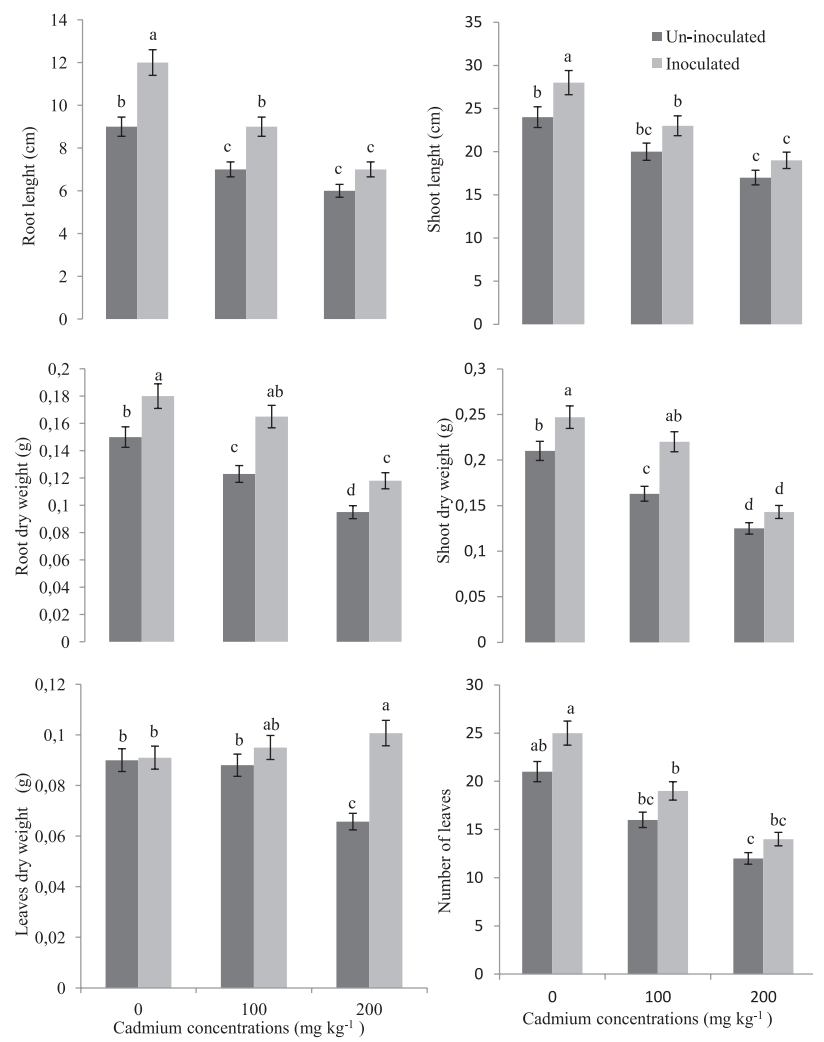

Fig. 1. Effect of Acinetobacter sp. CS9 on growth attributes of $C$. longifolius grown in Cd-contaminated soil; data presented are the means \pm SD from three replicates of each treatment; values with different letters demonstrate significant differences at $P \leq 0.05$. 
under $200 \mathrm{mg} \mathrm{kg} \mathrm{kg}^{-1} \mathrm{Cd}$, respectively, as compared to corresponding un-inoculated treatment.

The plants may tolerate heavy metal contamination up to certain limit above which plants exhibit symptoms of metal phytotoxicity [37]. It was revealed that $\mathrm{Cd}$ reduces plant growth and biomass production in a dose-dependent manner. Some other researchers have also reported the negative effect of Cd stress on growth and biomass production of subjected plants [38-39]. The reduced biomass production may be a result of $\mathrm{Cd}$ phytotoxicity that reduces nutrient uptake and photosynthetic activity in plants [40]. The stress may reduce turgidity of plant cells [41]. Results of the previous study also revealed that bacteria inoculation increased biomass production in Solanum nigrum plants subjected to Cd stress [42]. The bacteria capable of synthesizing auxin and with phosphate solubilization capability boost plant growth by increasing cell division and elongation, root initiation, and stress alleviation [43-44].

\section{Effect of Bacterial Inoculation on Physiological traits of C. longifolius Plants}

The $C$. longifolius were challenged by being grown in soils amended with different concentrations of $\mathrm{Cd}$. The physiological parameters such as activity of antioxidant enzymes (CAT, POD, SOD) and quantification of MDA, chlorophyll, soluble sugar, and protein contents were employed to determine the extent of Cd stress in C. longifolius plants. During our current study, uninoculated $C$. longifolius plants exhibited enhanced SOD activities in $100 \mathrm{mg} \mathrm{kg}^{-1} \mathrm{Cd}$ as compared to un-contaminated control. However, relatively decreased SOD activities were observed in $200 \mathrm{mg} \mathrm{kg}^{-1} \mathrm{Cd}$ in contrast to $100 \mathrm{mg} \mathrm{kg}^{-1} \mathrm{Cd}$ (Fig. 2). On the other hand, the inoculation of Acinetobactor sp. CS9 improved activities of SOD in the leaves and roots of $C$. longifolius under 0 , 100 , and $200 \mathrm{mg} \mathrm{Cd} \mathrm{kg}^{-1}$ soils as compared to respective uninoculated treatments. During our present experiments, CAT activities decreased when un-inoculated plants were subjected to higher concentrations of $\mathrm{Cd}$. The inoculated plants showed relatively higher CAT activity in contrast to respective un-inoculated treatment. The inoculated C. longifolius plants showed $32 \%$ and $13 \%$ reduced POD activity in their leaves under 100 and $200 \mathrm{mg} \mathrm{kg}^{-1}$ Cd-treated soils as compared to corresponding uninoculated treatments, respectively. A similar trend of decreased POD activity was observed in roots of inoculated plants subjected to $\mathrm{Cd}$ stress (Fig. 2). The increased activity of antioxidant enzymes may reduce the production of ROS in plants under stress. The current study revealed increased levels of CAT and SOD in plants under Cd stress [45]. The activity of these enzymes was further increased in inoculated plants under Cd stress. However, increased POD activity was observed in plants growing in Cd-contaminated soils. The inoculated plants exhibited reduced POD activity in all treatments as compared to respective un-inoculated treatment. Our results regarding POD activity are in accordance with already reported findings by some researchers [46].

The quantity of soluble sugar contents in plant leaves was dose dependent and reduced by increasing the concentration of $\mathrm{Cd}$ in soils. However, the application of Acinetobactor sp. CS9 further improved the amount of soluble sugar contents in C. longifolius as compared to un-inoculated control (Fig. 3). Reduced SPAD values were observed in plants under $\mathrm{Cd}$ stress. This reduction in chlorophyll content was dose-dependent and least chlorophyll contents were recorded in un-inoculated plants grown in $200 \mathrm{mg} \mathrm{kg}^{-1} \mathrm{Cd}$. The bacterial inoculation improved chlorophyll contents in all treatments in contrast to respective un-inoculated plants. Significantly low soluble protein contents were observed in $200 \mathrm{mg} \mathrm{kg}^{-1} \mathrm{Cd}$-treated soils compared to un-contaminated control. The inoculated $C$. longifolius plants showed relatively higher soluble protein contents in their leaves and roots in contrast with corresponding un-inoculated plants.

It has been observed that metal-resistant growthpromoting rhizobacteria improve photosynthetic contents and subsequent plant growth in plants growing under heavy metal stress [47]. Some researchers have revealed that plants exhibit reduced total sugar contents under stress [48]. However, inoculation of growth-promoting bacteria enhance both total sugar and protein contents
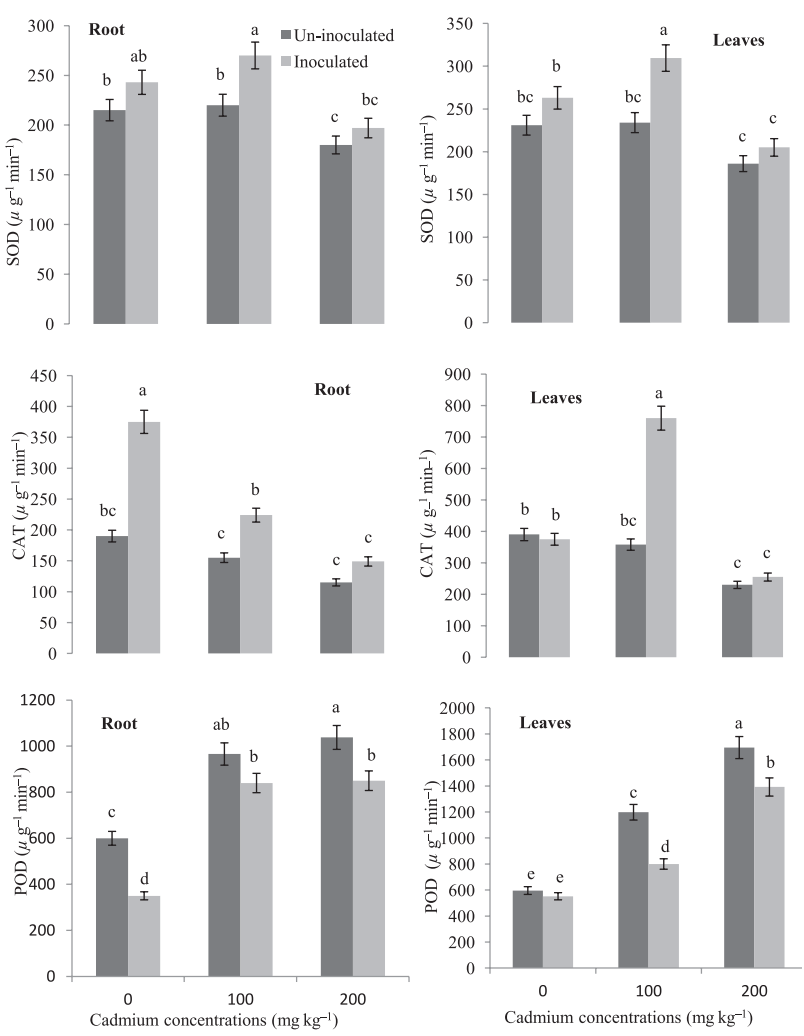

Fig. 2. Effect of Acinetobacter sp. CS9 on the antioxidant enzymes of $C$. longifolius grown in Cd-contaminated soil; data presented are the means \pm SD from three replicates of each treatment; values with different letters demonstrate significant differences at $P \leq 0.05$. 

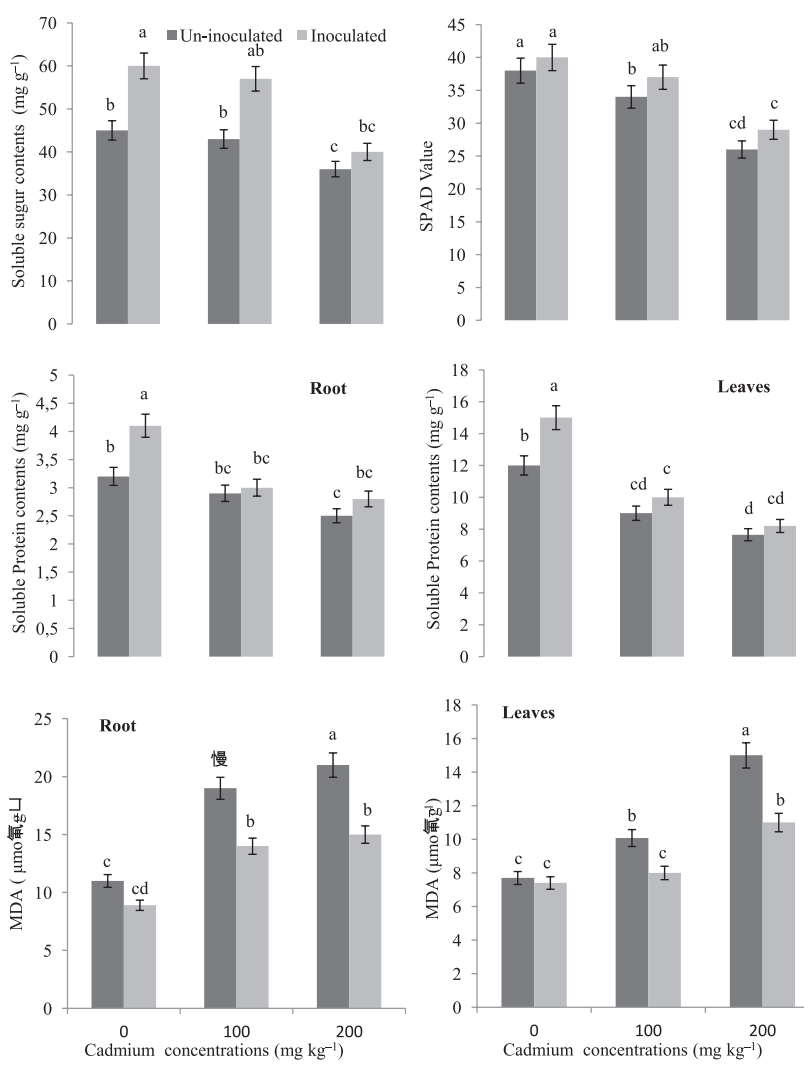

Fig. 3. Effect of Acinetobacter sp. CS9 on soluble sugar, SPAD value, soluble protein, and MDA of $C$. longifolius grown in Cd-contaminated soil; data presented are the means \pm SD from three replicates of each treatment; values with different letters demonstrate significant differences at $P \leq 0.05$.

in metal-stressed plants and help in alleviating relative stress [49-50].

Higher MDA levels in plants were observed at higher $\mathrm{Cd}$ concentrations. However, inoculated plants showed relatively low MDA contents as compared to corresponding un-inoculated plants under $\mathrm{Cd}$ stress (Fig. 3). The reduced MDA contents in inoculated plants advocate for Acinetobacter sp. CS9 helping mitigate Cdinduced oxidative stress [51].

\section{Effect of Acinetobactor sp. CS9 on Bioavailability and Uptake of $\mathrm{Cd}$}

The value of water-extractable $\mathrm{Cd}$ in un-inoculated soil was 9 and $17 \mathrm{mg} \mathrm{kg}^{-1}$ under $100 \mathrm{mg} \mathrm{kg}^{-1} \mathrm{Cd}_{\text {and }}$ $200 \mathrm{mg} \mathrm{kg}^{-1} \mathrm{Cd}$-amended soil, respectively. However, bacterial inoculation increased the value of waterextractable $\mathrm{Cd}$ up to $41 \%$ and $26 \%$ in $100 \mathrm{mg} \mathrm{kg}^{-1} \mathrm{Cd}$ and $200 \mathrm{mg} \mathrm{kg}^{-1} \mathrm{Cd}$-treated soils, respectively, as compared to corresponding un-inoculated soils (Fig. 4). During the present study, higher contents of Cd were observed in roots as compared to aerial parts of C. longifolius plants under Cd stress. The cadmium may be absorbed in roots through symplastic or apoplastic pathways [52]. Similar to our findings, higher Cd contents were observed in roots of tall fescue and bluegrass plants


Fig. 4. Effect of Acinetobacter sp. CS9 on water-extractable $\mathrm{Cd}$ from soil, Cd accumulation (roots, stems, and leaves), TF, and $\mathrm{BCF}$ of $C$. longifolius grown in Cd-contaminated soil; data presented are the means \pm SD from three replicates of each treatment; values with different letters demonstrate significant differences at $P \leq 0.05$.

subjected to $\mathrm{Cd}$ stress [53]. The un-inoculated plants exhibited 41,8 , and $15 \mathrm{mg} \mathrm{kg}^{-1} \mathrm{Cd}$ uptake in their roots, leaves, and shoots, respectively, under $100 \mathrm{mg} \mathrm{kg}^{-1} \mathrm{Cd}$. Moreover, the un-inoculated plants showed 98, 17, and $26 \mathrm{mg} \mathrm{kg}^{-1} \mathrm{Cd}$ in their roots, leaves, and shoots under $200 \mathrm{mg} \mathrm{kg}^{-1} \mathrm{Cd}$, respectively. After bacterial inoculation, the Cd uptake enhanced up to $29 \%, 41 \%$, and $46 \%$ in the roots, leaves, and shoots under $100 \mathrm{mg} \mathrm{kg}^{-1} \mathrm{Cd}$, respectively. Similarly, the $\mathrm{Cd}$ accumulation enhanced up to $25 \%, 37 \%$, and $39 \%$ in roots, leaves, and shoots of inoculated C. longifolius plants, respectively, as compared to relevant un-inoculated treatments. During the current study, Cd translocation from root to shoot was significantly improved in Acinetobactor sp. CS9inoculated plants grown in $100 \mathrm{mg} \mathrm{kg}{ }^{-1} \mathrm{Cd}$-amended soils as compared to un-inoculated ones. Similarly, the bioconcentration factor of $\mathrm{Cd}$ also significantly enhanced in inoculated $C$. longifolius plants treated with $100 \mathrm{mg} \mathrm{kg}^{-1} \mathrm{Cd}$ in contrast to un-inoculated plants. With the application of Acinetobactor sp. CS9 on C. longifolius plants, the TF and BCF increased up to $13 \%$ and $38 \%$ under $200 \mathrm{mg} \mathrm{kg}^{-1} \mathrm{Cd}$ with respect to corresponding un-inoculated treatments, respectively (Fig. 4).

The symbiotic relationships between plant-microbes play a key role in phytoremediation of Cd-polluted soils 
[54]. Growth-promoting bacteria may alleviate metal stress by restricting the movement of metalloids in roots or the dilution of metal contents within specific tissues of assisted plants [55]. Heavy metals obstruct the uptake and translocation of phosphorus and other nutrients in plants. Nevertheless, bacteria capable of synthesizing IAA with phosphate-solubilizing capability boost nutrient uptake, stress mitigation, and phytoremediation in assisted plants [56]. Similarly, Acinetobacter sp. CS9 is capable of producing siderophore, which may have increased Cd mobility toward plants, resulting in enhanced phytoextraction by inoculated plants [57]. The present results show that Acinetobacter sp. CS9 is capable of reducing $\mathrm{Cd}$ phytotoxicity in inoculated $C$. longifolius plants by increasing the quantity of photosynthetic pigments, shoots, and root growth, along with subsequent biomass production. The improved biomass enhances $\mathrm{Cd}$ phytoextraction in inoculated plants. In general, the current study shows that Acinetobacter sp. CS9 may mitigate Cd stress and improve the phytoextraction potential of $C$. longifolius plants.

\section{Conclusions}

The current study demonstrates that Acinetobacter sp. CS9 improves stress alleviation, growth, and phytoremediation potential of $C$. longifolius under $\mathrm{Cd}$ stress. The growth-promoting attributes of this bacterial isolate such as capability for siderophore production, phosphate solubilization, ACCD, and auxin production makes it an ideal candidate for exploitation in trials regarding metal stress alleviation and phytoremediation. The further genetic and molecular research will help to elucidate plant-microbe synergistic relationships to develop effective phytoremediation strategies.

\section{Acknowledgements}

The researchers extend their cordial gratitude to the laboratory and academic staff of the College of Earth and Environmental Sciences, University of the Punjab, Lahore and the Department of Botany, University of Sargodha for their sincere assistance and support during the completion of this study.

\section{Conflict of Interest}

The authors declare no conflict of interest.

\section{References}

1. HAMID A., RIAZ H., AKHTAR S., AHMAD S.R. Heavy Metal Contamination in Vegetables, Soil and Water and
Potential Health Risk Assessment. American-Eurasian Journal of Agricultural and Environmental Sciences, 16 (4), 786, 2016.

2. BIAN B., LIN C., LV L. Health risk assessment of heavy metals in soil-plant system amended with biogas slurry in Taihu basin, China. Environmental Science and Pollution Research, 23, 16955, doi: 10.1007/s11356-016-6712-3. 2016.

3. DATTA J.K., GHOSH D., BANERJEE A., KUMAR, MONDAL N. Studies on the Impact of cadmium on Growth, Yield Attributes, Yield and Biochemistry of Mung Bean (Vigna radiata L Wilczek) Under Natural Field Condition, Burdwan, West Bengal.. Scientia Agriculturae, 14 (1), 202, (DOI: 10.15192/PSCP.SA.2016.14.1.202209), 2016.

4. GALlEGO S.M., PENA L.B., BARCIA R.A., AZPILICUETA C.E., IANNONE M.F., ROSALES E.P., ZAWOZNIK M.S., GROPPA M.D., BENAVIDES M.P. Unravelling cadmium toxicity and tolerance in plants: insight into regulatory mechanisms. Environmental and Experimental Botany, 83, 33, 2012.

5. LIU K., YU F., CHEN M., ZHOU Z., CHEN C., LI M.S., ZHU J. A newly found manganese hyperaccumulator Polygonum lapathifolium Linn. International Journal of Phytoremediation, 18(4), 348, doi: 10.1080/15226514.2015.1109589, 2016.

6. HAMZAH A., HAPSARI R.I., WISNUBROTO E.I. Phytoremediation of Cadmium-contaminated agricultural land using indigenous plants. International Journal of Environmental and Agriculture Research, ISSN 24541850, 2(1), 2016.

7. KHAN W.U., AHMAD S.R., YASIN N.A., ALI A., AHMAD A. Effect of Pseudomonas fluorescens RB4 and Bacillus subtilis 189 on the phytoremediation potential of Catharanthus roseus (L.) in $\mathrm{Cu}$ and $\mathrm{Pb}$ contaminated soils. International Journal of Phytoremediation, 19 (6), 514, DO:10.1080/15226514.2016.1254154, 2017.

8. KUMAR S.P., VARMAN P.A.M., KUMARI R. Stress response in Catharanthus roseus leaves through proteomic approach. $10^{\text {th }}$ International Conference on Biology, Environment and Chemistry, 1, IACSIT press Singapore, 2011.

9. SUBHASHINI V., SWAMY A.V.V.S. Phytoremediation of $\mathrm{Pb}$ and $\mathrm{Ni}$ Contaminated Soils Using Catharanthus roseus (L.). Universal Journal of Environmental Research and Technology, 3 (4), 465, 2013.

10. EHSAN N., NAWAZ R., AHMAD S., KHAN M.M., HAYAT J. Phytoremediation of chromium contaminated soil by an ornamental plant Vinca (Vinca rosea L.). Journal of Environmental and Agricultural Sciences, 7, 29, 2016.

11. NOCTOR G., FOYER, C.H. Intracellular redox compartmentation and ROS-related communication in regulation and signaling. Plant Physiology, 171, 1581, 2016.

12. BOWLER C., MONTAGU M.V., INZE D. Superoxide dismutase and stress tolerance. Annual Reviews in Plant Physiology and Plant Molecular Biology, 43, 83, 1992.

13. GILL S.S., TUTEJA N. Reactive oxygen species and antioxidant machinery in abiotic stress tolerance in crop plants. Plant Physiology and Biochemistry, 48, 909, 2010.

14. ANDRADE S.A.L., GRA P.L., AZEVEDOB R.A., SILVEIRA A.P.D., SCHIAVINATO M.A. Biochemical and physiological changes in jack bean under mycorrhizal symbiosis growing in soil with increasing $\mathrm{Cu}$ concentrations. Environmental and Experimental Botany, 68, 198, 2010. 
15. SOBARIU D.L., FERTU D.I., DIACONU M., PAVEL L.V., HLIHOR R.M., DRĂGOI E.N., CURTEANU S., LENZ M., CORVINI P.F., GAVRILESCU M. Rhizobacteria and plant symbiosis in heavy metal uptake and its implications for soil bioremediation. N Biotechnology, 1871-6784 (16), 32403. doi: 10.1016/j.nbt.2016.09.002, 2016.

16. WU F.Y., HU J.L., WU S.C., WONG M.H. Grain yield and arsenic uptake of upland rice inoculated with arbuscular mycorrhizal fungi in As-spiked soils. Environmental Science and Pollution Research, 22, 8919, 2015.

17. KHAN W.U., YASIN N.A., AHMAD S.R., ALI A., AHMED S., AHMAD A. Role of Ni-tolerant Bacillus spp. and Althea rosea L. in the phytoremediation of Ni-contaminated soils. International Journal of Phytoremediation, 19 (5), 470, DOI: 10.1080/15226514.2016.1244167, 2017.

18. ULLAH A., HENG S., MUNIS M.F.H., FAHAD S., YANG X. Phytoremediation of heavy metals assisted by plant growth promoting (PGP) bacteria: A review. Environmental and Experimental Botany, 117, 28, 2015.

19. AHMAD I., AKHTAR M.J., ASGHAR H.N., GHAFOOR U., SHAHID M. Differential effects of plant growthpromoting rhizobacteria on maize growth and cadmium uptake. Journal of Plant Growth Regulation, 35 (2), 303, 2016.

20. KHAN W.U., AHMAD S.R., YASIN N.A., ALI A., AHMAD A., AKRAM W. Application of Bacillus megaterium MCR-8 improved phytoextraction and stress alleviation of nickel in Vinca rosea. International Journal of Phytoremediation, 19 (9), 813, DOI: 10.1080/15226514.2017.1290580, 2017.

21. GHAZIFARD K., TAVAKOL. Identification of bacteria resistant to heavy metals in the soils of Isahan provice. Iranian Journal Science and Technology, 31, 122, 2007.

22. SHRIVASTAVA A., SINGH V., JADON S., BHADAURIA S, Heavy metal tolerance of three different bacteria isolated from industrial effluents. International journal of pharmaceutical research and bio-science, 2, 137, 2013.

23. EUROPEAN FOOD SAFETY AUTHORITY, PARMA, ITALY (EFSA). Guidance on the assessment of bacterial susceptibility to antimicrobial of human and veterinary importance. EFSA Journal, 10 (6), 2740, 2012.

24. BERGEY D.H., HOLT J.G., KRIEG N.R., SNEATH P.H.A. Bergey' s manual of determinative bacteriology, 9th ed., (Breed RS, Murray EGD and Smith NR, eds.) WILLIAMS and WILKIMS, Baltimore, 1994.

25. YASIN N.A., ZAHEER M.M., KHAN W.U., AHMAD S.R., AHMAD A., ALI A., AKRAM W. The beneficial role of potassium in Cd-induced stress alleviation and growth improvement in Gladiolus grandiflora L. International Journal of Phytoremediation, (accepted), 2017.

26. SARWAR M., KREMER R.J. Enhanced suppression of plant growth through production of L-tryptophanderived compounds by deleterious rhizobacteria. Plant and Soil, 172, 261, 1995

27. PIKOVSKYAYA R.I. Mobilization of phosphorus in soil in connection with vital capacity of source microbial species. Microbiologia, 17, 326, 1948.

28. SCHWYN B., NEILANDS J.B. Universal chemical assay for detection and determination of siderophores. Analytical Biochemistry, 160, 47, 1987.

29. HONMA M., SHIMOMURA T. Metabolism of 1-aminocyclopropane-1carboxylicacid. Agricultural Biology and Chemistry, 42, 1825, DOI:10.1271/ bbb1961.42.1825, 1978.
30. ZHOU W, QIN S., LYU D., ZHANG P. Soil sterilisation and plant growth-promoting rhizobacteria promote root respiration and growth of sweet cherry rootstocks. Archives of Agronomy and Soil Science, 61(3), 361, 2015.

31. HEATH R.L., PACKER L. Photoperoxidation in isolated chloroplasts. I. Kinetics and stoichiometry of fatty acid peroxidation. Archives of Biochemistry and Biophysics, 125, 189, 1968.

32. BRADFORD M.M. A rapid and sensitive method for the quantitation of microgram quantities of protein utilizing the principle of protein-dye binding. Analytical Biochemistry, 72 (1-2), 248, DOI: 10.1016/0003-2697 (76) 90527, 1976.

33. GIANNOPOLITIS C.N., RIES S.K. Superoxide dismutases: I. Occurrence in higher plants. Plant Physiology, 59 (2), 309, DOI: 10.1104/pp.59.2.309, 1977.

34. HAVIR E.A., MCHALE N.A. Biochemical and developmental characterization of multiple forms of catalase in tobacco leaves. Plant Physiology, 84 (2), 450, DOI: $10.1104 / p p .84 .2 .450,1987$.

35. FIELDING J.L., HALL J.L. A biochemical and cytological study of peroxidase activity in roots of Pisum sativum. Journal of Experimental Botany, 29, 969, 1978.

36. SHIELDS R., BURNETT W. Determination of proteinbound carbohydrate in serum by a modified anthrone method. Analytical Chemistry, 32, 885, 1960.

37. LIN Y.F., AARTS M.G. The molecular mechanism of zinc and cadmi-um stress response in plants. Cell and Molecular Life Sciences, 69, 3187, 2012.

38. HOSSAIN M.A., PIYATIDA P., DA-SILVA J.A.T., FUJITA M. Molecular mechanism of heavy metal toxicity and tolerance in plants: central role of glutathione in detoxification of reactive oxygen species and methylglyoxal and in heavy metal chelation. Journal of Botany, 2012, 37, DOI:10.1155/2012/872875, 2012.

39. NIE J., LIU Y., ZENG G., ZHENG B., TAN X., LIU H., XIE J., GAN C., LIU W. Cadmium accumulation and tolerance of Macleaya cordata: a newly potential plant for sustainable phytoremediation in Cd-contaminated soil. Environmental Science and Pollution Research, DOI 10.1007/s11356-016-6263-7, 2016.

40. KHAN A.R., ULLAH I., KHAN A.L., PARK G.S., WAQAS M., HONG S.J., JUNG B.K., KWAK Y., LEE I., SHIN J.H. Improvement in phytoremediation potential of Solanum nigrum under cadmium contamination through endophytic assisted Serratia sp. RSC-14 inoculation. Environmental Science and Pollution Research， 22， 14032， doi:10.1007/s11356-015-4647-8, 2015.

41. KANG S.M., KHAN A.L., WAQAS M., YOU Y.H., KIM J.H., KIM J.G., HAMAYUN M., LEE I.J. Plant growthpromoting rhi-zobacteria reduce adverse effects of salinity and osmotic stress by regulating phytohormones and antioxidants in Cucumis sativus. Journal of Plant International, 9, 673, 2014.

42. MOHAMMADZADEH A., TAVAKOLI M., MOTESHAREZADEH M., CHAICHI M.R. Effects of plant growth-promoting bacteria on the phytoremediation of cadmium-contaminated soil by sunflower. Archives of Agronomy and Soil Sciences, DOI:10.1080/03650340.2016 .1235781, 2016.

43. GHOSH P., RATHINASABAPATHI B., MA L.Q. Arsenic-resistant bacteria solubilized arsenic in the growth media and increased growth of arsenic hyperaccumulator Pteris vittata L. Bioresource Technology, 102, 8756, 2011. 
44. MESA V., NAVAZAS A., GONZÁLEZ-GIL R., GONZÁLEZ A., WEYENS N., LAUGA B., JOSELUIS R., SÁNCHEZ G.J., PELÁEZ A.I. Use of endophytic and rhizosphere bacteria to improve phytoremediation of arsenic-contaminated industrial soils by autochthonous Betula celtiberica. Applied \& Environmental Microbiology, 10, doi:10.1128/AEM.0341116, 2017.

45. GRATÃO P.L., MONTEIRO C.C., TEZOTTO T., CARVALHO R.F., ALVES L.R, PETERS L.P., AZEVEDO R.A. Cadmium stress antioxidant responses and root-to-shoot communication in grafted tomato plants. Biometals, 28(5), 803, DOI: 10.1007/s10534-015-9867-3. Epub 2015 Jun 16. 2015.

46. WANG Q., XIONG D., ZHAO P., YU X., TU B., WANG G. Effect of applying an arsenic-resistant and plantgrowth promoting rhizobacterium to enhance soil arsenic phytoremediation by Populus deltoides LH05-17. Journal of Applied Microbiology, 111, 1065, 2011.

47. ISLAM F., YASMEEN T., ALI Q., MUBIN M., ALI S., ARIF M.S., HUSSAIN S., RIAZ M., ABBAS F. Copper-resistant bacteria reduces oxidative stress and uptake of copper in lentil plants: potential for bacterial bioremediation. Environmental Science and Pollution Research, 23, 220, DOI 10.1007/s11356-015-5354-1, 2016.

48. SANDHYA V., ALI Z.S.K., GROVER M., REDDY G., Venkateswarlu B. Effect of plant growth promoting Pseudomonas spp. on compatible solutes, antioxidant status and plant growth of maize under drought stres. Plant Growth Regulation, 62 (1), 21, 2010.

49. NASEEM H., BANO A. Role of plant growth-promoting rhizobacteria and their exopolysaccharide in drought tolerance of maize. Journal of Plant Interactions, 9(1), 689, DOI: 10.1080/17429145.2014.902125, 2014.

50. FANG Q., FAN Z., XIE Y., WANG X., LI K., LIU Y. Screening and evaluation of the bioremediation potential of $\mathrm{Cu} / \mathrm{Zn}$-resistant, autochthonous Acinetobacter sp.
FQ-44 from Sonchus oleraceus L. Frontiers in Plant Sciences, 7, 1487. DOI: 10.3389/fpls.2016.01487, 2016.

51. MOHAMED A.A., CASTAGNA A., RANIERI A., SANITA D.I. TOPPI L. Cadmium tolerance in Brassica juncea roots and shoots is affected by antioxidant status and phytochelatin biosynthesis. Plant Physiology and Biochemistry, 57, 15, 2012.

52. KUSHWAHA A., RANI R., KUMAR, S., GAUTAM A. Heavy metal detoxification and tolerance mechanisms in plants: implications for phytoremediation. Environmental Reviews, 24, 39, 2016. DOI: 10.1139/er-2015-0010.

53. DONG Q., XU P.X., WANG Z.L. Differential cadmium distribution and translocation in roots and shoots related to hyper-tolerance between tall Fescue and Kentucky blue grass. Frontiers in Plant Sciences. 8, 113, 2017. DOI: $10.3389 /$ fpls.2017.00113.

54. CHEN L., LUO S., LI X., WAN Y., CHEN J., LIU C. Interaction of Cd-hyperaccumulator Solanum nigrum L. and functional endophyte Pseudomonas sp. Lk9 on soil heavy metals uptake. Soil Biology and Biochemistry, 68, 300, 2014.

55. ASHRAF M.A., HUSSAIN I., RASHEED R., IQBAL M., RIAZ M., ARIF M.S. Advances in microbe-assisted reclamation of heavy metal contaminated soils over the last decade: A review. Journal of Environmental Management, 1 (198), 132, doi: 10.1016/j.jenvman.2017.04.060. Epub 2017 Apr 26, 2017.

56. PRAPAGDEEA B., CHANPRASERTA M., MONGKOLSUKB S. Bioaugmentation with cadmiumresistant plant growth-promoting rhizobacteria to assist cadmium phytoextraction by Helianthus annuus. Chemosphere, 92, 659, 2013.

57. DREWNIAK L., STYCZEK A., MAJDER-LOPATKA M., SKLODOWSKA A. Bacteria, hypertolerant to arsenic in the rocks of an ancient gold mine, and their potential role in dissemination of arsenic pollution. Environmental Pollution, 156, 1069, 2008. 
